\title{
The Dourmal of
}
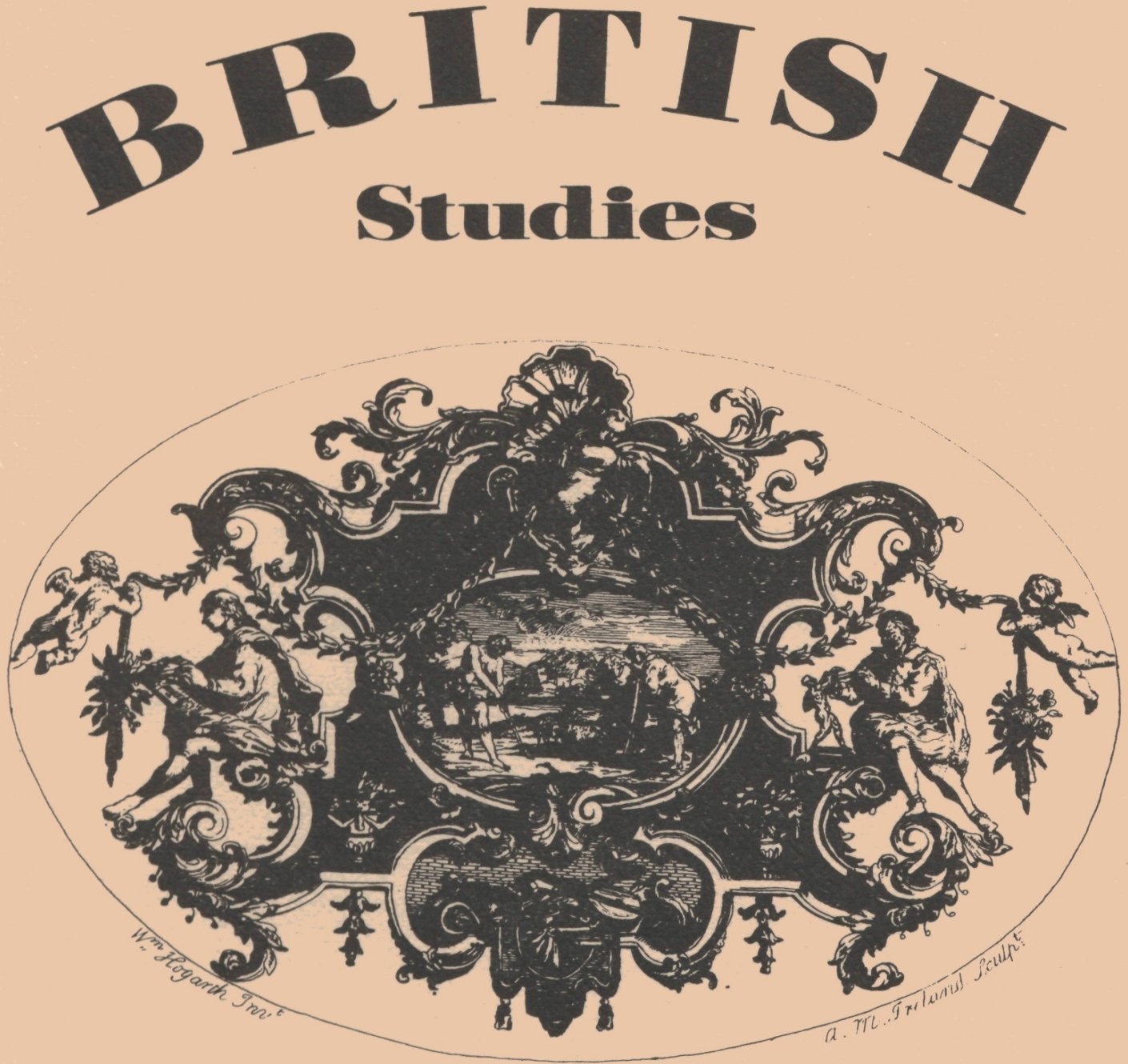

The Tankard 


\title{
From the library of Peter Stansky
}

\author{
JG EDITOR \\ Cooper, Trinity College \\ T EDITOR \\ ar
}

reter stansky, stunjura untuersuly

David Roberts, Dartmouth College

David Underdown, Brown University

BUSINESS MANAGER

Patricia A. McDonald

\section{BOARD OF ADVISORS}

H. J. Hanham, Massachusetts Institute

of Technology

Gertrude Himmelfarb, Graduate Center, City University of New York

Maurice Lee, Jr., Douglass College, Rutgers University

F. M. Leventhal, Boston University

Bryce Lyon, Brown University

W. T. MacCaffrey, Harvard University
Helen F. Mulvey, Connecticut College

Jacob M. Price, University of Michigan

Bernard Semmel, State University of New York, Stony Brook

Barbara Shapiro, University of California, Berkeley

Robert A. Smith, Emory University

Robin W. Winks, Yale University

\section{OVERSEAS CORRESPONDENTS}

Barbara Harvey, Somerville College, Oxford

Harold Perkin, University of Lancaster Keith Thomas, St. John's College, Oxford

\section{CONFERENCE ON BRITISH STUDIES}

\section{PRESIDENT}

Lacey Baldwin Smith, Northwestern University

ASSOCIATE EXECUTIVE SECRETARY

Reba N. Soffer, California State University, Northridge

RECORDING SECRETARY

Esther Cope, University of Nebraska

\section{EXECUTIVE SECRETARY}

Jacob M. Price, University of Michigan, Ann Arbor

\section{TREASURER}

Stuart E. Prall, Queen's College, C.U.N.Y.

PROGRAM CHAIRMAN

Anthony Wohl, Vassar College
Annual subscription $\$ 8.00$ (two issues, Fall and Spring). Checks should be payable to the Jcurnal of British Studies and directed to British Studies, Box 1315, Trinity College, Hartford, Connecticut 06106.

Contributors should send two copies of their manuscripts along with return postage to the EditorDesignate: Bentley B. Gilbert, Department of History, University of Illinois at Chicago Circle, Chicago, Illinois 60680 .
Information concerning membership in the Conference on British Studies may be obtained by writing to Stuart Prall, Department of History, Queen's College, C.U.N.Y., Flushing, New York 11367.

COVER: Rubbing from a tankard belonging to the Clare Market Artists Club, by William Hogarth. Reproduced by kind permission of the Lewis Walpole Library, Farmington, Connecticut. 


\section{NOTES ON CONTRIBUTORS}

CLIVE EMSLEY is a Lecturer in History at the Open University. He has just completed a study of British society during the Revolution and Napoleonic wars to be published in 1979 . His present research concerns the machinery and maintenance of public order in Britain during the late eighteenth and early nineteenth centuries.

ARTHUR N. GILBERT is Associate Professor at the Graduate School of International Studies, University of Denver. He has written several articles on the eighteenth-century British Army and Navy and is now working on several more articles as well as a book on the history of military justice and sexual deviance in England.

HARRO MAXIMILIAN HÖPFL, Lecturer in Political Theory at the University of Lancaster, is the author of "John Poccck's New History of Political Thought" in the European Studies Review (April, 1975). He is currently researching the political thought of John Calvin.

HENRY HORWITZ, Professor of History at the University of Iowa, has written Parliament, Policy and Politics in the Reign of William III (1977). He is now researching business fortunes and their fate, 1660-1800.

BARBARA C. MALAMENT is a Fellow of the Society for the Humanities, Cornell University for 1977-78. She has written "The 'Economic Liberalism' of Sir Edward Coke," Yale Law Journal (1967) and has published articles on 19th and 20th-century England. She is currently editing a volume of essays on Early Modern Europe due to appear in 1978, and is completing a book on British Politics and the Crisis of 1931.

RICHARD MAXWELL is an instructor at Valparaiso University. He is the author of "G. M. Reynolds, Dickens, and the Mysteries of London" in Nineteenth-Century Fiction and "Hugo, Ainsworth, Dickens: City Life and the Novel in the Early 1840's" (forthcoming). He is writing a series of articles on Dickens and London.

DERYCK SCHREUDER is Chairman of the Department of History, Trent University, Peterborough, Ontario, Canada. He spent 1977-78 at the Australian National University, Canberra, as Research Fellow in the Research School of Social Sciences. He has published Gladstone and Kruger: Liberal Government and Colonial 'Home Rule', 1880-85 (1969), and a new book, The Scramble for Southern Africa: the Politics of Partition Re-appraised will appear this year. The author of a number of articles, he is currently working on a reappraisal of Gladstone's international politics. 